The Journal of

\title{
Communication \\ and Media Studies
}

The "Animated Empire" of Post-modern Heroes Japanese Anime on Italian TV in the Late 70s 
EDITOR

Mario Minichiello, University of Newcastle, Australia

ACTING DIRECTOR OF PUBLISHING

Jeremy Boehme, Common Ground Research Networks, USA

MANAGING EDITOR

Helen Repp, Common Ground Research Networks, USA

\section{ADVISORY BOARD}

The Advisory Board of the Communication and Media Studies Research Network recognizes the contribution of many in the evolution of the Research Network. The principal role of the Advisory Board has been, and is, to drive the overall intellectual direction of the Research Network. A full list of members can be found at https://oncommunicationmedia.com/about/advisory-board.

\section{PEER REVIEW}

Articles published in The Journal of Communication and Media Studies are peer reviewed using a two-way anonymous peer review model. Reviewers are active participants of the Communication and Media Studies Research Network or a thematically related Research Network. The publisher, editors, reviewers, and authors all agree upon the following standards of expected ethical behavior, which are based on the Committee on Publication Ethics (COPE) Core Practices. More information can be found at https://cgnetworks.org/journals/publication-ethics.

THE JOURNAL OF COMMUNICATION AND MEDIA STUDIES

https://oncommunicationmedia.com

ISSN: 2470-9247 (Print)

ISSN: $2470-9255$ (Online)

https://doi.org/10.18848/2470-9247/CGP (Journal)

First published by Common Ground Research Networks in 2020 University of Illinois Research Park

2001 South First Street, Suite 202

Champaign, IL 61820 USA

$\mathrm{Ph}:+1-217-328-0405$

https://cgnetworks.org

The Journal of Communication and Media Studies is a peer-reviewed, scholarly journal.

\section{COPYRIGHT}

(C) 2020 (individual papers), the author(s)

(C) 2020 (selection and editorial matter),

Common Ground Research Networks

\section{(우(1) $\odot \odot$}

Some Rights Reserved

Public Licensed Material: Available under the terms and conditions of the Creative Commons

Attribution-NonCommercial-NoDerivatives 4.0 International Public License (CC BY-NC-ND 4.0). The use of this material is permitted for non-commercial use provided the creator(s) and publisher receive attribution. No derivatives of this version are permitted. Official terms of this public license apply as indicated here: https://creativecommons.org/licenses/by-nc-nd/4.0/legalcode

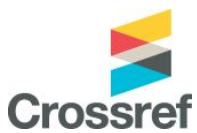

Common Ground Research Networks, a member of Crossref

\section{ARTICLE SUBMISSION}

The Journal of Communication and Media Studies publishes quarterly (March, June, September, December). To find out more about the submission process, please visit https://oncommunicationmedia.com/journal/call-for-papers.

\section{ABSTRACTING AND INDEXING}

For a full list of databases in which this journal is indexed, please visit https://oncommunicationmedia.com/journal.

\section{RESEARCH NETWORK MEMBERSHIP}

Authors in The Journal of Communication and Media Studies are members ofthe Communication and Media Studies Research Network or a thematically related Research Network. Members receive access to journal content. To find out more, visit https://oncommunicationmedia.com/about/become-a-member.

\section{SUBSCRIPTIONS}

The Journal of Communication and Media Studies is available in electronic and print formats. Subscribe to gain access to content from the current year and the entire backlist. Contact us at cgscholar.com/cg_support.

Single articles and issues are available from the journal bookstore at https://cgscholar.com/bookstore.

\section{HYBRID OPEN ACCESS}

The Journal of Communication and Media Studies is Hybrid Open Access, meaning authors can choose to make their articles open access. This allows their work to reach an even wider more, please visit

https://cgnetworks.org/journals/hybrid-open-access.

\section{DISCLAIMER}

The authors, editors, and publisher will not accept any legal responsibility for any errors or omissions that may have been made in this publication. The publisher makes no warranty, express or implied, with respect to the material contained herein.

\section{ORDERING} audience, broadening the dissemination of their research. To find out 


\title{
The "Animated Empire" of Post-modern Heroes: Japanese Anime on Italian TV in the Late 70s
}

\author{
Vincenzo Maselli, ${ }^{1}$ Sapienza University of Rome, Italy
}

\begin{abstract}
From Pacific regions to European countries, mass communication's history had been exposed to numerous revolutions in the late 70s and early 80s: new TV shows, networks, technologies, audio-visual products, and disciplines examining the relationship between culture and media appeared. In those years, the Japanese media industry exported a huge amount of animated series in European countries and, especially in Italy, Pacific heroes became dominators of private and public networks that broadcasted their stories daily with great success. This article aims at tracing factors that opened Italian purchasers and spectators to the new Pacific heroes and at defining this cultural and economic phenomenon as an "animated empire" built for the last forty years. These phenomena can be explained by summarizing political, economic, social, and technological events that occurred in both Japan and Italy in the 1970s, such as the energy crisis of 1973, the economic dynamism of Japanese animation studios and Italian TV networks in the late 1970s, and the post-modern revolution of Italian society. The article examines these converging factors and relies upon a research path that is not new to the Italian scene, with Marco Pellittieri, Saburo Murakami, Guido Travassi, Franco Colombo, Luca Raffaelli, and Roberta Ponticello among the leading exponents, some of whom are mentioned in the article. These researchers in the last two decades have associated the study of television as a cultural medium, made up of genres, formats and contents, with the historical and social analysis of the arrival and distribution patterns of anime in the Italian TV programming.
\end{abstract}

Keywords: Japanese Anime, Media Empire, Post-Modern Heroes, Italian Television, Converging Factors

\section{Introduction}

$\Lambda$ s the Italian scholar Marco Pellitteri (2014) illustrates, Italy has been one of the first European countries that, in the late 1970s, imported massive amounts of Japanese cartoons and broadcasted them on private networks. This phenomenon has been defined by several scholars as an anime boom, an expression used to describe with onomatopoeia, the explosion of the Japanese cartoon broadcasting in the late 1970s and early 1980s as a new entertainment product in Europe. This analysis follows a track of research not new in the Italian panorama, and that has been explored, in the last two decades, by Italian scholars such as Claudia Baglini (1998), Saburo Murakami (1998), Maria Novielli (2015), Marco Pellittieri (2006, 2008, 2014, 2008/2018), Roberta Ponticello (2007), Luca Raffaelli (1994/2018), Susanna Scrivo (2007), and Guido Tavassi (2012/2017). Their investigations combine the study of Italian television genres, formats and contents, and the analysis of the "explosive" impact anime had on the economic and media Italian system. By moving the attention from the "explosive entrance" to the charming and unstoppable conquer of Italian TV networks in that period, I suggest considering anime's success the beginning of an "animated empire" far from the end. In the 1980s television was the main centralized cultural influencing and attracting medium. By spreading and metaphorically dominating it, Japanese animated artefacts impacted the population; affected consumers' world view, perception, and behavior; and challenged opinions, imageries and traditions.

Italy, as mentioned, has been one of the first countries and the most enthusiastic buyer of Japanese animated series, with almost 700 anime purchased and broadcasted between 1978 and 2006 (Pellitteri 2014). Italian generalist networks broadcasted more anime than the rest of the European countries in the 1980s, followed closely by France and Spain (Malone 2010; Pellitteri 2012; Tavassi 2017). We have to wait for the mid 1990 s to see anime penetrate other countries

\footnotetext{
${ }^{1}$ Corresponding Author: Vincenzo Maselli, Via Flaminia 72, Department of "Planning, Design and Technology of Architecture”, Sapienza University of Rome, Rome, 00196, Italy. email: vincenzo.maselli@ uniroma1.it
}

The Journal of Communication and Media Studies

Volume 5, Issue 4, 2020, https://oncommunicationmedia.com

(C) Common Ground Research Networks, Vincenzo Maselli,

Some Rights Reserved (CC BY-NC-ND 4.0). Permissions: cgscholar.com/cg_support

ISSN: 2470-9247 (Print), ISSN: 2470-9255 (Online)

https://doi.org/10.18848/2470-9247/CGP/v05i04/35-45 (Article) 
such as the United Kingdom and the United States, where TV producers, by relying on a strong internal animation industry, in the beginning bought a paltry number of Japanese cartoons, even considering them a threat to the national industry (Siuyi Wong 2010; Tavassi 2017). ${ }^{2}$ The international diffusion of thematic TV channels and formats designed specifically for airing cartoon series in the 1990s (Hetherington 1997), and viewers increasing control on "what, when, and where to view from abundant options" during the "post-network era" ${ }^{3}$ in the middle-2000s (Lotz 2007, 15), made anime an "increasingly significant player in the global cultural economy" (Napier 2005, 5). In Italy the diffusion of a multichannel environment-consisting of thematic channels - and the globalization of national television systems occurred late, just "after the launch of a new satellite pay-TV platform, Sky Italia, in July 2003, and the introduction of digital terrestrial television (DTT)" (D'Arma 2010, 201). Nevertheless Japanese anime arrived on the national mass-audience channels and on the local networks long before experiencing the "multichannel revolution" (D'Arma 2010), and Pacific heroes successfully conquer and dominate Italian TV networks for decades. How did it happen? Which reasons can justify this extremely large and relentless distribution? I will answer these questions by shortly summarizing economic reasons that pushed Japan to "invade" the European media and communication market and analyzing the most relevant political, economic, social, and technological events that occurred in that period in the country that welcomed the Pacific heroes.

\section{The "Animated Empire"}

Before exploring the economic, technological, and social circumstances that in the 70s led Italy and Japan to, respectively, import and export anime, it would be worthwhile outlining the metaphorical deployment of the concept of empire applied to the Japanese animation industry. Empire is a potent historical phenomenon and, by definition, a material formation obtained by "extending a country's power and influence through diplomacy, or the use of military force" (Palmer et al. 2007, 630), with the aim of territorial expansion and domination. But empire has taken on other connotations over time and has been used metaphorically in the wider meaning of cultural and economic supremacy more than military. This new version of empire exponentially developed with capitalism and globalization, and has been facilitated by easier access to a broad range of media, "the increased importance of economic, cultural, and technological integration between countries, — and the-technological advancement all over the world" (Meenakshi 2017, 79). In this scenario the idea of media imperialism emerged. Since the 1990s, this phenomenon has been studied, dissected and defined trying to explore its dynamic essence, continuously adapting to cultural, social, economic and technological changes.

Media empires have been discussed as both a form of domination in which media is used by developed countries to economically, politically and culturally dominate underdeveloped nations and to force foreign contents towards them (Kalyani and Kavoori 2011; Reach 1987; Said 1993;

\footnotetext{
${ }^{2}$ Literature about anime in Western Courtiers is still limited, since Japanese animation products broadcasting occurred in different moment and conditions. As documented by Paul Malone (2010), in countries other than Italy, as Spain and France, shows such as Tezuka Osamu's Kimba the White Lion, for instance, was shown in the early 1970s, and soon followed by other series chosen for their "appeal to specifically European audience" (316), and at the end of the decade by the simultaneous arrival of numerous robot series. Beside the mentioned Italian researchers who documented and analyzed the Italian phenomenon, other studies have been conducted by Jiwon Ahn (2002), Anne Allison (2000), Jonathan Clements and Helen McCarthy (2006), Mary Grigsby (1998), Alfons Moliné (2002), Susan Napier (1993, 2001/2005) and many others, who have contributed to an understanding of how Japanese products have circulated in international contexts, and on how audience consumes them.

${ }^{3}$ In the book The Television Will Be Revolutionized (2007) Amanda Lotz classified three different eras of medium's history based on changes in content programming and distribution. In the classic network era (early 1950s to middle1980s) television was dominated by a few broadcast networks politically-oriented and with strong economic power. In the multi-channel transition era (middle-1980s to the middle-2000s) cable and satellite television channels emerged and "enabled a new abundance of viewing options" (13). In the current post-network era (started in the middle-2000s), ways audiences consume television completely change (mobile, online viewing, digital recording) and "the erosion of the control over how and when viewers watch particular programs" (15) occurs.
} 
Sung 1992; Tunstall 1977), and as a pacific exchange of information, visuals, images, technologies, sometimes ideologies between societies over a common communication platform (Boyd-Barrett 1977; Yang 2010). According to Ueno Toshiya (1996), telecommunications and technological infrastructures' silent and pacific contamination can be considered a "sub-empire," exchanging media artefacts, imageries, and productive scenarios. It is no coincidence that JeanGuy Rens (2001), while arguing about the Canadian telecommunications industry's earliest days, named the immaterial connecting platform played on the internet and not on occupied territories, as an invisible empire. Beside the pacific purpose of communication media, in the capitalistic scenario media imperialism has been addressed in negative terms as an obstacle to a socioeconomic balanced development of third world countries. According to Fed Fejes (1981, 281), "the growth of the media imperialism approach is one reflection of the general critical assessment and rejection by many Third World countries of Western models of modernization of which the earlier communication models were a part."

Whether the purpose is aggressive or pacific, media industries are driven by technological advancement and constantly expanding markets, and crucially contribute to the development of a complex system of interconnections and interdependencies between countries in a global perspective. Globalization is, of course, the key phenomenon in this scenario. "Globalization-as Meenakshi synthetize - [has] increased usage of mass media, ...facilitated cultural exchange, and multiplied the flow of information and images between countries through international news broadcasts, television programming films and music" $(2017,80)$.

Among many kinds of media artefacts, animated media has been subjected to a cultural hegemony of contents, languages, aesthetics, and characters in a scenario monopolized by only one American producer since the late 1930s and the entire decade of the1940s. Ueno Toshiya writes: "under the Fordist economic system of the past, globalization meant nothing more than 'Americanization,' with media entertainment being supplied by Disney and its animated works" (Toshiya 1996). Several scholars addressed Disney industries' hegemonic production as an "empire," (Bendazzi 1985; Rondolino 2016), and Walt as an "Industrial Knight" and a "founder of empires" (Bendazzi 1985, 249), as he built an entertainment empire artistically fascinating and technologically advanced. Music, technique, scenarios, imageries, stories, and skilled employers and collaborators perfectly matched with industrial ability and visionary selling strategies.

Disney international's success influenced animation productions around the world, and Mickey Mouse, Snow White, Bambi, and their animated "colleagues" imposed a standard in both their graphic appearance and the stories they experienced. Non-US animation studios soon started dialoguing, mimicking and borrowing visual elements, stories, and narrative structure from this model (Lu 2008; Pellitteri 2008). Japanese animated artefacts, as suggested by Amy Shirong Lu (2008, 170), got inspired by western visual style and "during the 1930's [...] were drawn in the style of the Disney and Warner Brothers' cartoons," but they quickly developed a distinctive style. Since the 1970s anime has addressed peculiar production, narrative, and design features that made their international appreciation. The extraordinary expansion and distribution of Japanese animated products, therefore, occurred in the late 1970s and throughout the 1980s at first just in a few European regions, and then in an international panorama, and was determined by a series of converging factors: a successful production strategy, fortunate economic and market conditions, and a charming aura of mystery, provocativeness, and either fantastic or futuristic contents. As aforementioned, Italian scholars titled this scenario as the "anime boom" to metaphorically address the massive amount of Japanese animated series imported by Italy and broadcasted on private TV networks as an explosion.

By applying the concept of "Media Empire" to the Japanese animation industries' increasing success in the late 1970s, I consider anime more than just entertainment products, and address them as transnational agents responsible for making Japanese culture able to spread values, traditions and imageries and making them acknowledged and appreciated internationally. 


\section{The Economic Power of Japan in the 60s and 70s}

After the defeat at the end of the Pacific War, Japan was militarily occupied by US troops under General Douglas MacArthur. The nation had to be completely rebuilt and the film production industry, as well as that of animation, experienced productive upheavals under the control of the Civil Information and Education Section (CIE) (Standish 2006; Tavassi 2017). Paradoxically, in the difficult years of the post-war period the animated medium survived above all thanks to a "dual policy of Prescription and Proscription" (Standish 2006, 154) followed by American authorities. On the one hand, Americans limited the freedom of expression, banned any sporting or artistic activity connected to the code of the ancient samurai (Ponticello and Scrivo 2007), and subjected films to "both pre-production and post-production censorship" (Standish 2006, 156). On the other, the former enemy from overseas allowed the rebirth and reconstruction of the Country's economy, financed the Japanese industry and promoted the production of films, as long as they staged 'appropriate' contents. As Isolde Standish stated in the book A New History of Japanese Cinema: A Century Of Narrative Film (2006, 155), "the CIE sought to encourage the development of ideas associated with American 'democracy' while preventing the media from disseminating anything considered unsuitable or dangerous to the Occupation Government." The Japanese economy in the 1950s grew enormously and families could finally lead a life with a higher standard of living and purchased for the first time goods such as household appliances: the refrigerator, the washing machine, the vacuum cleaner and, at the end of the decade, the television, initially called denki kamishibai (electric paper theatre) (Nash 2009). The advent of television, the new capitals available to the entertainment industry, alongside the flourishing and dynamic comics market (manga) - that constituted an immediate and inexhaustible source of inspiration-determined the birth of the modern anime industry. The production of television anime was inaugurated by the small Otogi production studio with Instant History (Figure 1) (dir. Ryuichi Yokoyama, Shin'ichi Suzuki, and Michihiro Matsuyama, 1961), a series of 312 threeminute episodes broadcasted by Fuji TV between 1961 and late 1962 (Tavassi 2017).

The Japanese economic miracle culminated in 1970 with the inauguration of the Osaka World Expo. In the 1970s the Japanese economic superpower gave further proof of its strength, facing the serious energy crisis of 1973 and placing an effective strategy of "reconversion of the heavy industry in manufactures with low energy consumption devoted to hi-tech, becoming thus a country at the forefront of research and development of new mechanical, electrical and electronic technologies" (Tavassi 2017, 109-110).

As documented by Guido Tavassi, anime soon reflected these transformations in narrated stories, and the science fiction genre seemed to be suitable to address these themes. The energy crisis of 1973, however, had also caused a slowdown in the rate of development in Japan, which had been unstoppable in the previous fifteen years, and a series of economic and productive consequences. The Yen was losing value, leading to a decline in labor costs. These conditions were ideal for entering into the international entertainment market with low-cost products appreciated by foreign customers first for being cheap and then for the original contents. 


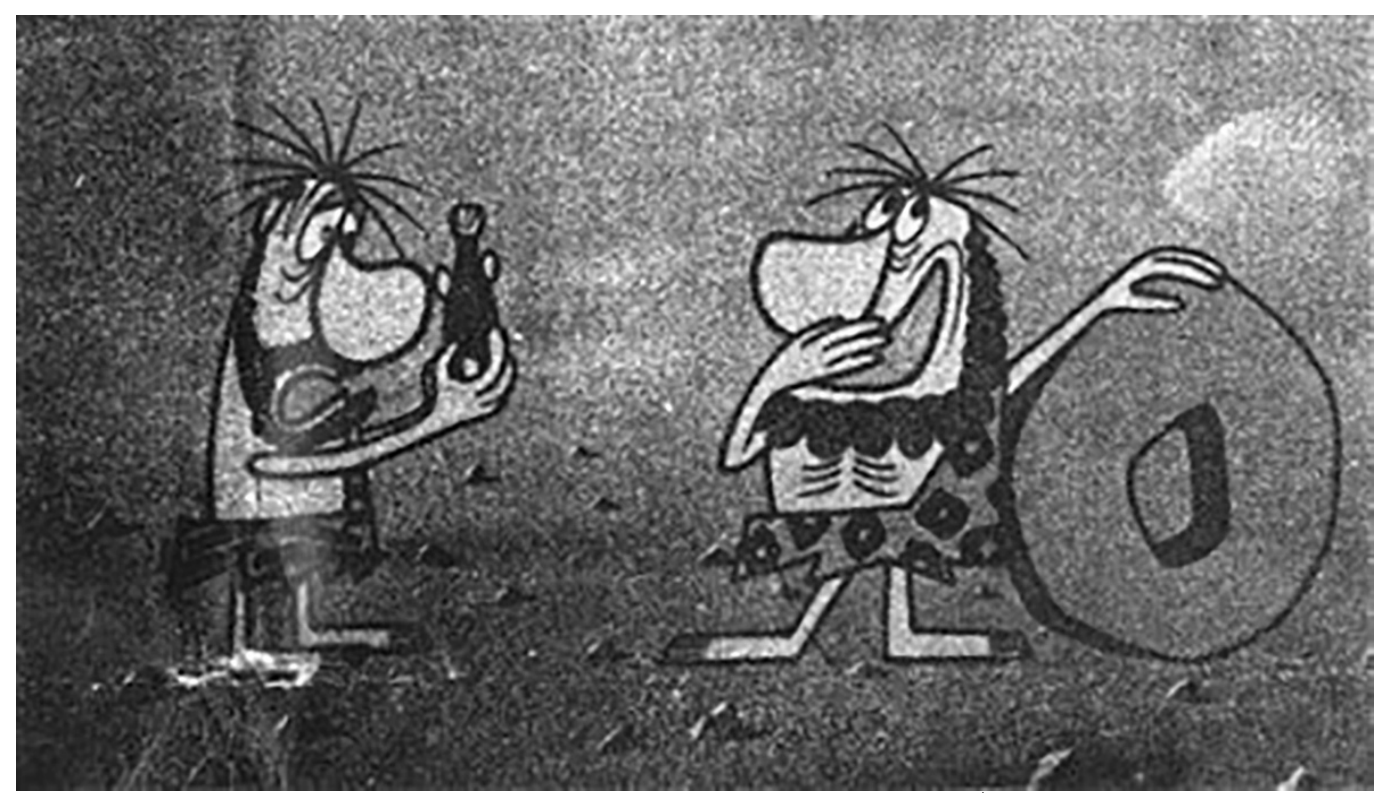

Figure 1: "Instant History" 1961-1962: Still Frame

Source: (C) Otogi Production

\section{The Post-modern Heroes into the Italian Society}

The conquest of Italian TV channels by Japanese animated series in the late 1970s and 1980s can be understood if we analyze converging factors of Italy's political, economic, social, and technological condition between the two decades. Due to the energy crisis, Italy, like all capitalist countries, experienced a strong wave of recession in the fall of 1973 with repercussions on its economy (Monteleone 2013). On the other hand, the crisis had caused unprecedented industrial dynamism and the interest of large publishing groups such as Mondadori, Rusconi, and Olivetti in the audio-visual product and in "the possibility of commercial use of the new techniques of electronic reproduction of images" (Monteleone 2013, 386). Meanwhile, the Italian Constitutional Court's jurisprudence revolutionized the mass communications production system. The first one, n. 225/1974, forbade the Italian National Television's (RAI) monopoly on broadcasting media; the second one, 226/1974, favored a first opening to private networks in local areas. From the summer of 1974, numerous local TV networks were born, including Telenorba, Telemontecarlo, Telesuperba, Qui Modena, and Savona TV. The Constitutional Court intervened again on the subject with case n. 202/1976, approving the official liberalization on a national scale. At the beginning of the new decade, the remote control had become a symbol of a new television language, in which the rhythms of programming increased, the times of each transmission decreased and there was much more choice of products and quality (Monteleone 2013). The flourishing and uncontrolled birth of private networks at the beginning of the $80 \mathrm{~s}$ gave rise to "the need to fill in as soon as possible and in the most economic way hours and hours of television programming still empty" (Pellitteri 2018, 339). Japanese anime, which had already been tasted in previous years with the Euro-Japanese co-productions, seemed to answer perfectly this need, together with the Latin American soap operas, as they were "TV shows ready and of discrete quality" (Pellitteri 2006, 57). The first entrance of anime into the European television

\footnotetext{
${ }^{4}$ The footage of this series is very rare, as most probably episodes were not recorded and the master tapes themselves were destroyed. Some still frames are available on the internet. The selected frame possibly comes from an episode focusing on the prehistoric times.
} 
market came, as mentioned, under the formula of the co-productions. ${ }^{5}$ Some European television companies and animation studios asked Japanese studios to either co-produce or sponsor the production of animated series. The condition was that "these series [had to be] based on European stories or characters, and their styles [had to be] as close as possible to a European taste, combined with the Japanese technical and linguistic sensitivity" (Tavassi 2017, 157) (Figure 2).

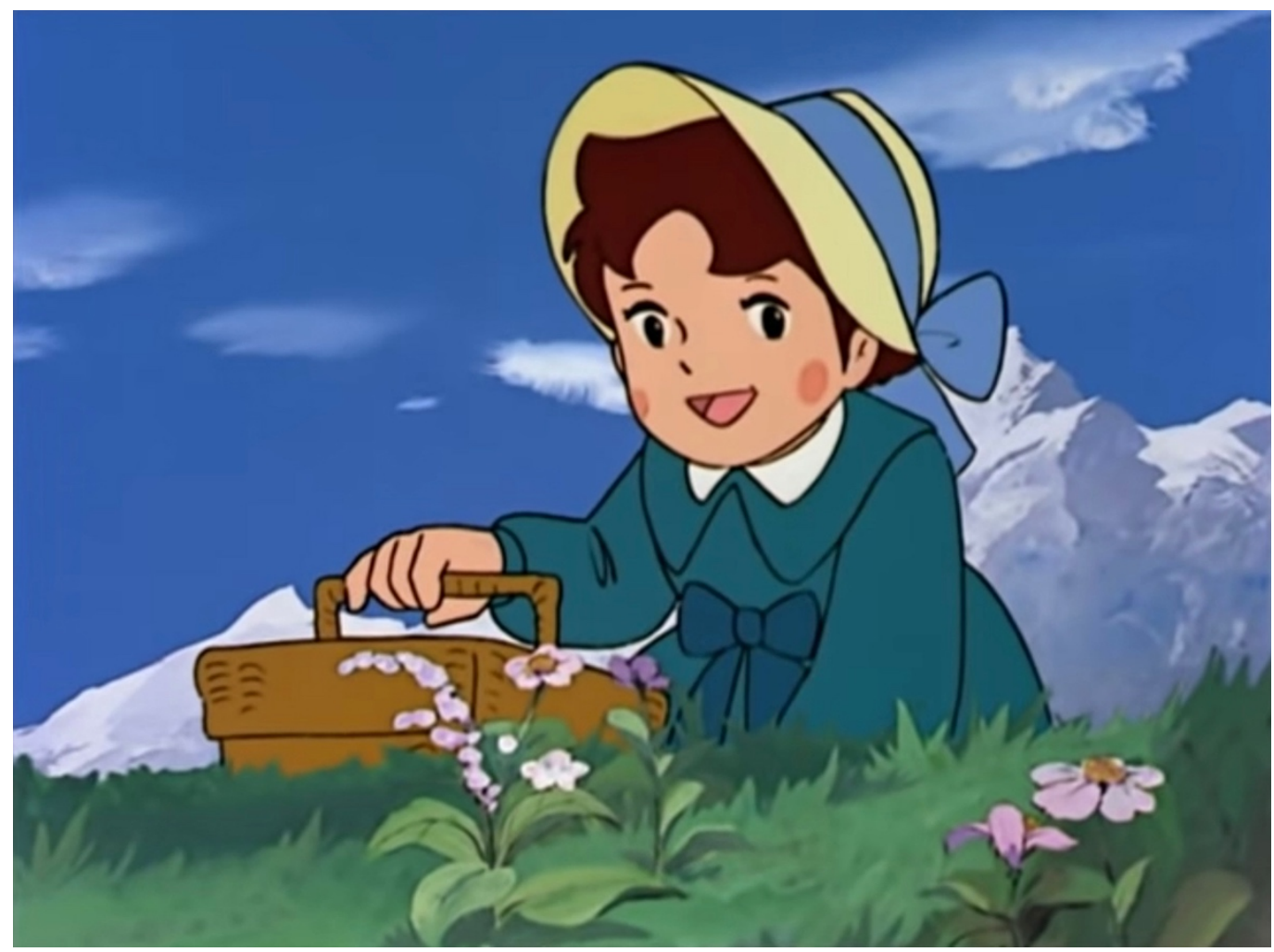

Figure 2: "Heidi, Girl of the Alps" 1974, Episode No. 34: Still Frame Source: (C) Zuiyo / Nippon Animation

In addition to the good value for money there were other reasons:

- These audio-visual products were serial and allowed the organization of daily appointments "replicating the same pattern or programs every day of the week" (Monteleone 2013, 450).

- The attractive contractual conditions granted by Japanese producers to European buyers, as they allowed for heavy adjustments and changes to the original versions of the series.

- The economy of the product due to low labor costs and the aforementioned Yen devaluation.

\footnotetext{
${ }^{5}$ These collaborations gave life to the first Japanese animated series broadcasted between 1976 and 1978 in Belgium, France, Germany, Italy, Spain and Switzerland: Barbapapa (dir. Atsushi Takagi, Katsuhisa Yamada, Kouichi Sasaki, 1974), Vickie the Viking (dir. Hiroshi Saito, 1974), Heidi, Girl of the Alps (dir. Isao Takahata, 1974) and Marco, From the Apennines to the Andes (dir. Isao Takahata, 1975).
} 
In a social perspective, Italy was experiencing a transformation in the family organization that contributed to the success of the Pacific heroes. The beginning of a new family structure in urban centers was one of the changes that post-modernism brought. In the 1980s middle-class mothers were full-time workers, and it had become a routine for children to spend their afternoons in the company of "those new and fascinating adventures from Japan that came into their homes through their television" (Pellitteri 2018, 338). ISTAT and ISTEL data collected by Elisa Manna and Alberto Pellai about the percentages of young people who watched Japanese cartoons in the 1980s and 1990s are representative of this new situation. According to ISTEL in the early 1980s, about 80 percent of boys between the ages of eight and fourteen were regular spectators of Japanese heroes, compared to much higher percentages collected by ISTAT data, according to which almost 100 percent of children between 5 and 11 years old in the early $90 \mathrm{~s}$ watched Japanese anime on TV (Manna 1982; Pellai 1999). The popularity that these series obtained among Italian children and adolescents was caused, as mentioned, by two characteristics: the broadcasting methods and the contents. The daily repetition of the series in Italy was, in part, the reason for their success, since the heroes accompanied children and young people daily with long series that could range from twenty-six to fifty-two episodes (Tavassi 2017; Pellitteri 2018). Apart from the afore mentioned Europe-Japan co-productions, whose stories were classics of children's western literature, the first Japanese heroes in the late 70s were robots, new and attractive paladins for boys, violent and dangerous for parents. In Italy, in fact, the anime boom began with Atlas Ufo Robot Goldrake (Figure 3) (dir. Masayuki Akehi, Tomoharu Katsumata, Masamune Ochiai, 1975) in April 1978 on the TV show "Buonesera con..." that usually broadcasted American animated series. ${ }^{6}$ Goldrake in Italy was the forefather of a generation of mechanical heroes.

Despite a simplified animation technique compared to American standards, Japanese productions focused on the centrality of stories, on articulated narrative plots, tormented protagonists and on "emotional directorial choices" (Ponticello and Scrivo 2007, 29-30). To use the words of Pellitteri $(2008,18)$, "no more gentle little pictures with animal acting in relaxing scenarios with comic intents; [...] but dramas in which heroes often died tragically, and in which strong themes are dealt without many filters for small spectators."

These tormented and super-technological characters weaved a close relationship with the young spectators of post-modern society, who often shared a profound and unconscious solitude with these same heroes. The sociologist Kiyomitsu Yui in the article Japanese Animation and Glocalization of Sociology (2010) reflects on the postmodern value of anime and includes a series of features of the society that welcomed the Japanese series. He talks about "predisposition toward the post-modern condition" of the new generations of young people who show characteristics such as:

- "Fragmentation of time and pace" (46) accentuated with the arrival of the internet.

- "Aestheticization of daily life" (46) and the opening to new and foreign aesthetics.

- "Deconstruction of the subject" (46) questioning himself and the world around him, proving to be attracted to the transcendent and magic dimension of the transmitted contents.

- "De-differentiation of borders" (47), which leads to a nuance of national, ethnic, cultural differences, and of the differences between original and copy and between real and fictitious.

- "Breakdown of grand narrative [in favour of] many different small narratives and stories from every corner of the world, each having its own 'exotic' flavour" (47).

\footnotetext{
${ }^{6}$ The arrival of Atlas UFO robot Goldrake on Italian TV is deeply described by Pellitteri in Mazinga Nostalgia (2018), 344-361.
} 
The technological aspects of Italy in the early 1980s are the final characterizing factor of this event of extraordinary proportions. Between 1975 and 1980 in Italy the mass communications sector experienced several technological innovations. Video games-new playful equipment based on dynamic interaction with the electronic medium-joined electronic media products such as radio and television. This new relationship with technology merged perfectly with the imaginary that the robotic heroes had helped to forge and with the theme of the man-machine relationship. It is no coincidence that Pellitteri $(2008,18)$ writes: "Goldrake and the Japanese anime of the science fiction genre emphasised the entrance into a new phase of the media: that...of the 'fusion' between technology and man." This change of the imaginary came together with the diffusion of color TVs in Italy in the 1970s, which allowed the broadcasting of colorful imported animated series and significantly increased their popularity (Ponticello and Scrivo 2007).

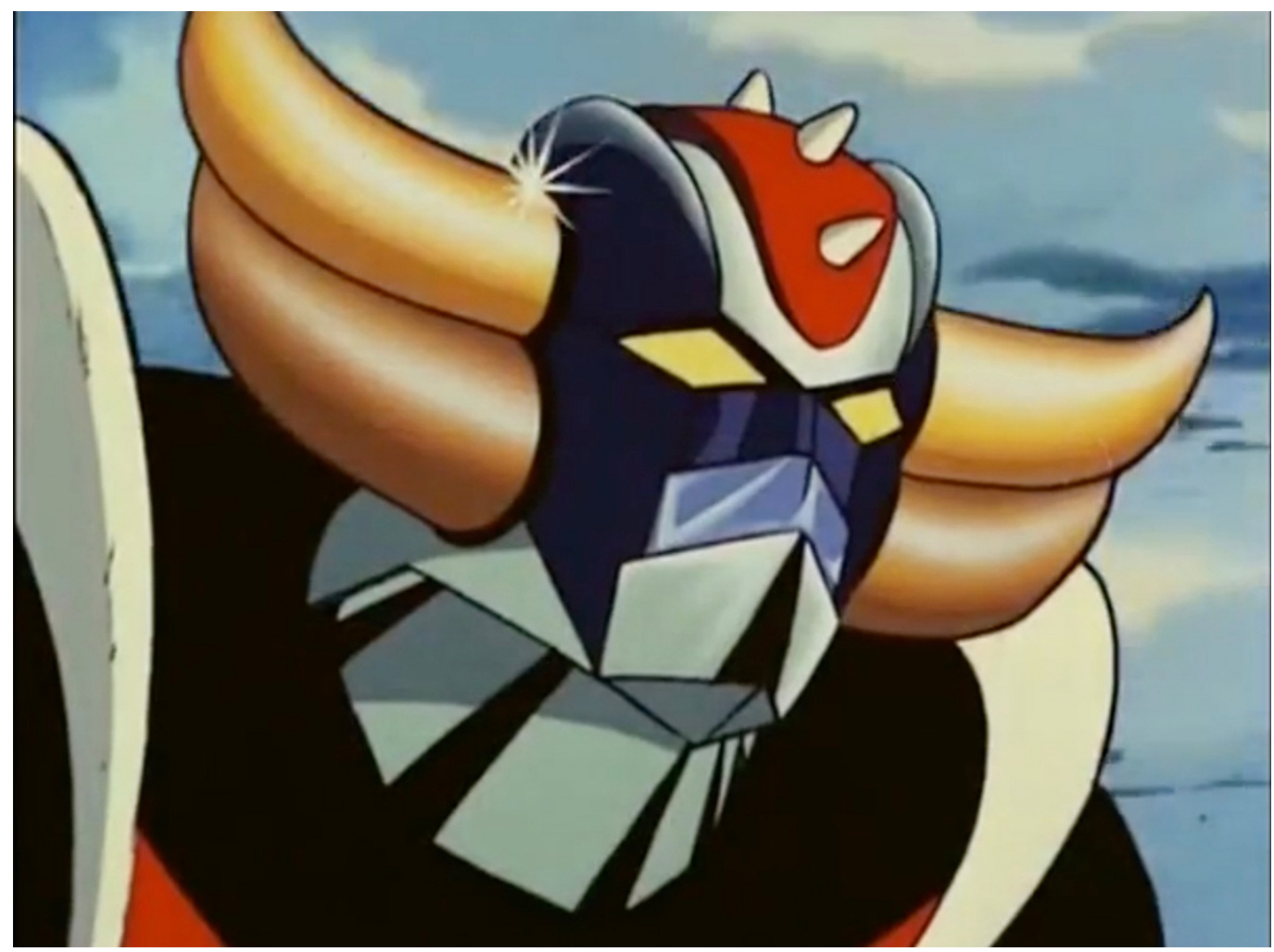

Figure 3: "Ufo Robot Goldrake" 1978, Episode No. 1: Still Frame Source: (C) Toei Animation / Dynamic Planning, Inc.

\section{Conclusion: Forty Years of Pacific Heroes}

The anime boom in Italy occurred between 1978 and 1984 in the condition just described, but this diffusion, despite unstoppable, was sometimes obstructed and heavily criticized. After arriving on the promising Italian entertainment market, anime had to oppose a "Eurocentric closure" (Pellitteri 2008, 320) and the stories were judged too real and cruel, because they often spoke also of death. For years public opinion condemned anime as too violent or too explicit. These accusations were partly due to a profound misunderstanding of the product's target, as American Disney productions had accustomed the public to combining animation with the 
children's public. ${ }^{7}$ On the other hand, in recent years several scholars have begun to recognize anime as a pedagogical value, as well as an undeniable impact on the economic and media system. According to Daniela Sarsini (2012, 50), emotions, involvement and strong identification with animated characters make animation an "effective educational tool." Sarsini focused on animated series targeted to pre-schoolers and produced in Europe; the analyses of scholars such as Pellitteri, Tavassi, Ponticello and Scrivo, instead, demonstrate that Japanese animation can rightly be considered a case of "informal" education, as it allows viewers to live a relational and communicative experience, and to learn "without institutions or organizations manifestly assigned to the purpose, and without a declared pedagogical intention" (Tramma 2009, 36). Anime pedagogical value has many aspects yet to be investigated, connected to both the Japanese cultural features, the social contexts in which Japanese animation landed at the end of the 1970s, and the globalization of cultures and converging of imaginations it encouraged. According to Jiwon Ahn (2002, 20), Japanese animation is "the most personal yet social activity, and the most schizophrenic yet possibly liberating experience in the context of globalization." Anime expand the concept of education and learning by providing different kinds of experiences: "visual, acoustic, metaphorical, phenomenological, perceptive-motor" (Sarsini 2021, 50). Children and adolescents of an entire generation, according to Pellitteri, through the magical transformations, the difficult decisions, the denials, the anxieties, the worries, the desires and the spirit of responsibility of the heroes coming from the pacific, have done "the generals rehearsal of the future lives into the adult world" (Pellitteri 2018, 951), and have been able to dream of living adventures with companions from worlds in which magic exists, technology is very advanced, and in which fortitude and determination can challenge gravity and subvert its principles.

From the 80 s to the present, stories have evolved, distribution channels have changed, and the target has been extended and differentiated by intensity of interest, sex and age, but the extraordinary nature of the imaginary and the depth of the themes continue to be undeniable qualities of Japanese anime. Therefore, today we can recognize and appreciate the consequences, the pedagogic value and the cathartic power of the "animated empire" Pacific heroes silently but effectively have built in Italy for the last forty years.

\section{REFERENCES}

Ahn, Jiwon. 2002. "Animated Subjects: On the Circulation of Japanese Animation as Global Cultural Products." Spectator - The University of Southern California Journal of Film and Television 22 (1): 10-22.

Allison, Anne. 2000. "A Challenge to Hollywood? Japanese Character Goods Hit the U.S." Japanese Studies 20 (1): 67-88. https://doi.org/10.1080/10371390050009075.

Baglini, Claudia. 1998. "È un Uccello? È un Aereo? È Goldrake!: Gli Anime Invadono la Televisione Italiana" [Is it a Bird? Is it a Plane? It's Goldrake! Anime Invade Italian Television]. IF: Immagini \& Fumetti 25 (8): 48-57.

Bendazzi, Giannalbero. 1985. "Un Cavaliere d'Industria [The Industry Knight].” In Walt Disney, edited by E. Bruno and E. Ghezzi. Venice: La Biennale, "Cinema e Spettacolo Televisivo" Sector.

Boyd-Barrett, Oliver. 1977. "Media Imperialism: Towards an International Framework for the Analysis of Media Systems.” In Mass Communication and Society, edited by J. Curran, M. Gurevitch, and J. Wallacott. London: Edward Arnold.

\footnotetext{
${ }^{7}$ In Japanese anime's spectators are divided by age and gender: pre-school children, adolescents, post-adolescent youngsters, and adult consumers. Animation is not a entertainment form for the exclusive use of children, but an audiovisual product capable of adapting effectively to different audiences.
} 
Constitutional Court. 9 July 1974, no. 225. http://www.giurcost.org/decisioni/1974/0225s74.html.

Constitutional Court. 9 July 1974, no. 226. http://www.giurcost.org/decisioni/1974/0226s74.html.

D’Arma, Alessandro. 2010. "Italian Television in the Multichannel Age: Change and Continuity in Industry Structure, Programming and Consumption." Convergence: The International Journal of Research into New Media Technologies 16 (2): 201-215. https://doi.org/10.1177/1354856509357685.

Fejes, Fred. 1981. "Media Imperialism: an Assessment," Media Culture \& Society 3 (3): 281289. https://doi.org/10.1177/016344378100300306.

Grigsby, Mary. 1998. "Sailormoon: Manga (Comics) and Anime (Cartoon). Superheroine Meets Barbie: Global Entertainment Commodity Comes to the United States." Journal of Popular Culture 32 (1): 59-80. https://doi.org/10.1111/j.0022-3840.1998.3201_59.x.

Hetherington, Janet L. 1997. “As Mainframe's Technology Reaches Adolescence, there's a 'ReBoot' Renaissance." Animation Magazine 11 (8).

Kalyani, Chadha, and Anandam Kavoori. 2011. "Media Imperialism Revisited: Some Findings from the Asian Case." Media Culture \& Society 4 (3): 231-240. https://doi.org/10.1177/016344300022004003.

Lotz, Amanda D. 2007. The Television will be Revolutionized. New York: NYU Press.

Lu, Amy Shirong. 2008. "The Many Faces of Internationalization in Japanese Anime”, Animation: an Interdisciplinary Journal 3 (2): 169-187. https://doi.org/10.1177/1746847708091893.

Manna, Elisa. 1982. Età Evolutiva e Televisione. Livelli di Analisi e Dimensioni della Fruizione [Age of Growth and Television. Levels of Analysis and Dimensions of Fruition]. Turin: ERI.

Meenakshi. 2017. "A Study of Media Imperialism Process Factors and its Impact on Indian Television Industry." PhD diss., Kurukshetra University.

Moliné, Alfons. 2002. El Gran Libro de los Manga [The Big Book of Manga]. Barcelona: Ediciones Glénat.

Monteleone, Franco. 2013. Storia della Radio e della Televisione In Italia, VII ed. [Italian Radio and Television History]. Venice: Marsilio Editori.

Murakami, Saburo. 1998. Anime in TV. Storia dei Cartoni Animati Giapponesi Prodotti per la Televisione [Anime on TV. History of Japanese Cartoons Produced for Television]. Milano: Yamato Video.

Napier, Susan. 1993. "Panic Sites: The Japanese Imagination of Disaster from Godzilla to Akira." Journal of Japanese Studies 19 (2): 327-351. https://doi.org/10.2307/132643.

Napier, Susan. 2001/2006. Anime from Akira to Princess Mononoke: Experiencing Contemporary Japanese Animation. New York: Palgrave Macmillan.

Nash, Eric P. 2009. Manga Kamishibai: The Art of Japanese Paper Theater. New York: Abrams Comicarts.

Novielli, Maria R. 2015. Animerama. Storia del Cinema d'Animazione Giapponese [Animerama. History of Japanese Animated Cinema]. Venezia: Marsilio.

Palmer, Robert R., Joel Colton, and Lloyd Kramer. 2007. A History of the Modern World, 10th ed. Boston: McGraw-Hill College.

Pellai, Alberto. 1999. Teen Television. Gli Adolescenti Davanti e Dentro la TV [Teen Television. Teenagers in Front of and inside the TV]. Milan: FrancoAngeli.

Pellitteri, Marco. 2006. "Manga in Italy. History of a Powerful Cultural Hybridization." International Journal of Comic Art 8: 56-76.

2008. Il Drago e la Saetta. Modelli, Strategie e Identità dell'Immaginario Giapponese [The Dragon and the Lightning Bolt. Japanese Imagination's Models, Strategies and Identities]. Latina: Tunué. 
2014. "The Italian Anime Boom: The Outstanding Success of Japanese Animation in Italy, 1978-1984." Journal of Italian Cinema \& Media Studies 2 (3): 363-381. https://doi.org/10.1386/jicms.2.3.363_1.

2008/2018. Mazinga Nostalgia. Storia, Valori e Linguaggi della Goldrake-Generation dal 1978 al Nuovo Secolo, IV ed. [Mazinga Nostalgia. Goldrake-Generation History, Values and Linguistic Codes from 1978 to the New Century]. Latina: Tunué.

Ponticello, Roberta, and Susanna Scrivo. 2007. Con gli Occhi a Mandorla. Sguardi sul Giappone dei Cartoon e dei Fumetti [With Almond-Shaped Eyes. Looks on Japan of Cartoons and Comics]. Latina: Tunuè.

Raffaelli, Luca. 1994/2018. Le Anime Disegnate. Il Pensiero nei Cartoon da Disney ai Giapponesi e Oltre [The Drawn Souls. The Thought in Cartoons from Disney to the Japanese and Beyond]. Latina: Tunué.

Rens, Jean-Guy. 2001. The Invisible Empire: A History of the Telecommunications Industry in Canada, 1846-1956. Kingston, Ontario: Queen's School of Policy Studies.

Roach, Colleen. 1987. "The US Position on the New World Information and Communication Order." Journal of Communication $37 \quad$ (4): $36-51$. https://doi.org/10.1111/j.1460-2466.1987.tb01007.x.

Rondolino, Gianni. 2016. Storia del Cinema d'Animazione [Animation Cinema History]. Torino: UTET Distribuzione, 2016.

Said, Edward. 1993. Culture and Imperialism. London: Chatto and Windus.

Sarsini, Daniela. 2021. "Infanzia e Cartoon: Alcune Riflessioni Pedagogiche" [Childhood and Cartoon: Some Pedagogical Thoughts]. Studi sulla Formazione 1: 47-61. https://doi.org/10.13128/Studi_Formaz-11647.

Standish, Isolde. 2006. A New History of Japanese Cinema: A Century of Narrative Film. London: Continuum International Publishing Group ltd.

Sung, Liching. 1992. "Setting the Agenda for the Future." Telecommunication Policy 16 (8): 624-634. https://doi.org/10.1080/00220485.2019.1582386.

Tavassi, Guido. 2012/2017. Storia dell'Animazione Giapponese: Autori, Arte, Industria, Successo dal 1917 a Oggi [Japanese Animation History: Authors, Art, Industry, Success from 1917 to Today]. Latina: Tunué.

Toshiya, Ueno. 1996. “Japanimation and Techno-Orientalism." Documentary Box 9. https://www.yidff.jp/docbox.

Tramma, Sergio. 2009. Che Cos'è l'Educazione Informale [What Is Informal Education]. Roma: Carocci.

Tunstall, Jeremy. 1977. The Media are American: Anglo American Media in the World. London: Constable.

Yui, Kiyomitsu. 2010. "Japanese Animation and Glocalization of Sociology." Sociologisk Forskning 47 (4): 44-50. https://www.jstor.org/stable/20853739.

\section{ABOUT THE AUTHOR}

Vincenzo Maselli: Research Fellow, Department of Planning, Design, and Technology of Architecture, Sapienza University of Rome, Rome, Italy 
The Journal of Communication and Media Studies offers an interdisciplinary forum for the discussion of the role of the media and communications in society. The journal explores everyday experiences of media cultures, the forms and effects of technologies of media and communications, and the dynamics of media business. It also addresses media literacies, including capacities to "read" and "use" the media, and the role of media as a key component in formal and informal learning. Contributions to the journal range from broad, theoretical conceptualizations of media, to detailed empirical examinations and case studies of media practices.

The Journal of Communication and Media Studies is a peer-reviewed, scholarly journal. 